\title{
Pedagogisk, psykologisk og medisinsk behandling av kriminelle.
}

\author{
Af professor, dr. med. öRNULV öDEGÅRD, Oslo.
}

Når behandling av kriminelle er stillet opp som diskusjonsemne ved dette møte, har tanken nok for en del vært å få drøftet behandlingen som en modsetning til straffen, - de to begreper som motsatte midler i individualprevensjonens tjeneste. Det er nyttig å legge stor vekt på det som skiller mellem straff og behandling - fordi det er denne klare motsetningen som danner det beste grunnlag når det gjelder å planlegge et reformprogram i fangebehandlingen. Men når det gjelder å nå frem til enighet om den praktiske gjennemf $ø$ relse av et slikt program, er det likeså nyttig å bli klar over at motsetningen ikke er absolutt, og at straff og behandling har likhetspunkter som gjør skillet mellem disse begrepene mindre skarpt. Selv den rene gjengjeldelse inneholder elementer av behandling, fordi den kan føre til f $\phi$ lelsesmessig avlastning både for forbryteren og for det samfund som gir ham straffen: ved soningen og hevnen. Dybdepsykologien har lært oss at når slike tendenser har fått så dyp rot i menneskesinnet og i samfundsformene, er det nettopp fordi de fyller psykologiske behov, og dermed på et vis får "psykoterapeutiske“ funksjoner. (Dermed er ikke ment at disse momenter er nok til å gjøre gjengjeldelsesprinsippet berettiget eller forsvarlig).

Det avskrekkende ved straffen har også berøringspunkter med visse former for behandling — særlig de som bygger på betingede reflekser (som aversjonskuren mot alkoholisme). Faren ved en slik avskrekkende behandling er bl. a. at hvis angsten kommer for sterkt frem, kan den likefrem virke som en kriminogen faktor: i sexualforbrytelsene (særlig i exhibisjonismen) er angsten en av de drivende krefter.

Både straff og behandling kan være ubehagelig for den det går ut over, og det kan ofte tvistes om hva som er den største lidelse: ex 30 dagers fengsel, eller tre års arbeidsskole. Det er riktignok så at ved straffen er dette onde tilsiktet. Men det er ikke alltid lett å skjelne mellem de tilsiktede onder ved straffen og de uundgåelige ved behandlingen, iallfall når man ser på det fra fangens (pasientens) synspunkt. Dette har også en dypere mening, fordi det hos den som behandler har lett for å komme ubevisste tendenser frem som har med straff å gjøre. Slikt er vanlig i den psykoterapeutiske situasjon, og vedkommende terapeut beh $\varnothing$ ver ikke selv å være oppmerksom på det.

De forskjellige former for straff som brukes idag, gir ikke alle samme mulighet for kombinasjon med behandling. Det er innlysende at en langvarig fengselsstraff muliggjør en personlig terapeutisk påvirkning, mens kortvarige innesperringer i så måte er av liten verdi. Slike straffearter som betinget dom, betinget undlatelse av påtale, prøvel $\phi$ s- 
1atelse og overhodet all friere behandling av kriminelle er utpreget terapeutiske $\mathrm{i}$ hele sin tankegang. Visse former for straff kan sies å inneholde et element av behandling, ved at de fører inn det prinsipp at man skal erstatte ved eget arbeide for den skade man har voldt andre.

En meget vesentlig forskjell mellem straff og behandling er at straffen blir utmålt etter handlingens art, og dermed er bestemt - mens behandlingen etter sitt vesen må vare til den er kronet med held, og dermed blir ubestemt i tid. I praksis blir denne forskjell utjevnet, fordi straff kan gis et mere ubestemt preg, og fordi der også for internering i behandlings $\phi$ yemed må settes maksimums- og minimumstider. En langt mere avgjørende forskjell ligger i holdningen - den sjelelige inn'stilling hos fangen og hos den som straffer eller behandler ham. Det er denne "terapeutiske situasjon" som bestemmer om noen behandling overhodet foregår. Men selv om begge parter har det фnske at dette skal være en behandlings-situasjon, vil likevel ubevisste tendenser hos dem begge kunne bringe straffen inn, uten at noen av dem er oppmerksom på det. Og hvis ikke begge parter har behandlings-innstillingen, står man straks overfor noe som mere virker som en straffesituasjon. Den veltjente fengselsfunksjonærs vanskeligheter når han flyttes over fra en straffe-anstalt til et behandlingssted illustrerer dette.

En viktig praktisk forskjell ligger deri at straffen som regel settes i verk uten så fullstendig forundersøkelse av personen som når det tas sikte på behandling. En slik personundersøkelse tjener ikke bare diagnosen og klassifiseringen, men danner bakgrunnen for det personlige forhold som er grunnlaget for at en psykoterapeutisk situasjon skal kunne oppstå - et personlig forhold som bygger på at den ene har kjennskap til den annens problemer, og at pasienten (fangen) på sin side anerkjenner at den behandlende har et slikt kjennskap. Derfor er det uheldig at den psykiatriske obeservasjon i regelen blir foretatt av andre enn de som senere får med den dømte å gjøre. Det arbeide som er lagt i observasjonen, blir på den måten terapeutisk forgjeves, og det er til og med mulig at en slik rent diagnostisk unders $\varphi$ kelse kan gi fangen en negativ innstilling til senere personunders $\varnothing$ kelser i behandlings $\varnothing$ yemed.

Utviklingen i nyere tid har gått mot en utviskning av grensene mellem behandling og straff - i f $\varnothing$ rste rekke ved at våre straffeanstalter har fått et $\phi$ kende behandlingspreg og hele vårt straffesystem er blitt humanisert. Men den utviskede avgrensning henger også sammen med at våre fors $\phi \mathrm{k}$ på å etablere en virkelig behandling hittil har vært famlende, og at den „behandling" vi hittil har kunnet by våre kriminelle derfor ikke har vært fri for straffepreget. Det jeg har fors $\phi$ kt i det foregående, er imidlertid å vise at mangelen på absolutt motsetning mellem straff og behandling for en del er uundgåelig, fordi den bunder i disse to begrepenes eget vesen. 
En inndeling av behandlingen etter arten i medisinsk, psykologisk og pedagogisk, slik det er gjort i titelen på vårt diskusjonstema, er i praksis ikke lett å gjennemføre. Lettere er det å trekke opp klare linjer på grunnlag av praktiske kriterier, som for eks. en inndeling etter det sted hvor behandlingen foregår. Det viktigste spørsmål i denne forbindelse er om vi skal beholde det skarpe skille som idag s $\phi$ kes trukket mellem våre tradisjonelle straffeanstalter og de nyere behandlingsanstalter som etterhvert bygges ut. Det kan jo nemlig være spørsmål om isteden å s $\varnothing$ ke å utjevne dette skille. Hvad bygningene angår er det selv idag liten prinsipiell forskjell på de krav som stilles: I begge tilfelle må vi ha bygninger som er hygenisk forsvarlige og som tilfredsstiller visse sikkerhetshensyn, samtidig. som de gjør en tålelig tilværelse mulig. Begge typer av anstalter må gi mulighet for klassifikasjon, og må derfor helst være delte og forsynt med annekser for større frihet. Muligens vil en behandlingsanstalt måtte ha større plass for sykehusmessige enheter - men også et fengsel må ha sin sykeavdeling for interkurrente sykdommer av somatisk og psykisk art. Derfor er det rimelig at en st $\varnothing$ rre anstalt som idag skal bygges, vil falle omtrent ens ut enten den er planlagt for det ene eller det annet formål.

Et annet praktisk skille ligger $i$ beleggets art. Hvis en anstalt har et belegg som oppfatter sitt opphold der som en straff, så vil oppholdet dermed også få preget av straff, selv om ledelsen hårdnakket hevder at det er en behandling. Og kan man omvendt få belegget til å akseptere interneringen som ledd $i$ en behandling, har man tatt et stort skritt hen imot behandlingsanstalten. Dette virker selvsagt begge veier - og av naturlige grunner er det anstaltsledelsen som må bære det største ansvar for utfallet. Muligens kan straff og behandling foregå på samme anstalt overfor forskjellige grupper av belegget. Dette vil alltid være vanskelig å gjennemf $\varnothing$ re. På enhver anstalt må det riktignok være en viss plass for disiplinærstraffer, selv under forløpet av en behandling. Men det er den vesentlige forskjell at disse straffer jo gjeller småforseelser i dagliglivet, mens den idømte straff gjeller den opprindelige forbrytelse.

Vi er her inne på spørsmålet om den kriminelles sjelelige egenart. Her er det enighet om at sinnssyke overhode ikke skal straffes, men bare ha behandling. Det samme gjeller stort sett om personer med lettere sjelelige anomalier som åndssvake og psykopater, og jo mere avvikende sinnstilstanden er, desto mere vil behandlingen måtte dominere over straffen. Mere tvilsomt kan spørsmålet stille seg når det gjeller fanger som er psykisk normale etter en vanlig psykiatrisk bedømmelse. (Det kan hevdes prinsipielt at ingen som har begått en straffbar handling er helt psykisk normal, men i praksis vil en slik konsekvent holdning ikke la seg gjennemføre). Sålenge man holder på straff som det primære overfor normale kriminelle, og behandling som det primære overfor psykisk abnorme, vil det være nødvendig å skille dem ad på skillte anstalter. Hvis grensen mellem straff og behandling skal s $\varnothing$ kes utvisket vil det kunne vise seg praktisk å behandle endel 
lettere abnorme sammen med de normale fanger, slik at behovet for spesialanstalter ikke blir så stort.

Skal man gå inn på en tredeling i medisinsk, pedagogisk og psykologisk behandling, vil man st $\varnothing$ te på vanskeligheter om man prøver å finne de saklige grenser mellem disse tre behandlingsformer. I praksis er dette neppe heller n $\phi$ dvendig, da det vil være tilstrekkelig å bruke som inndelingsgrunnlag det personale som utfører behandlingen. Medisinsk blir da all behandling som fortrinsvis utføres av medisinsk trenet personell - psykologisk blir den som utf $\phi$ res av spesialutdannede psykologer - mens endelig den pedagogiske behandling er den som utføres av pedagoger. Det er en klar forskjell mellem disse tre grupper av personell når det gjeller utdannelse, praktisk erfaring og metoder. Delvis vil det også bli en forskjell i de mål de setter for sin behandling, og i deres personlige innstilling til oppgaven. Disse forskjeller vil være lettere å få $\phi y e$ på enn forskjellene i det daglige arbeide de utfører med fangene, som for en stor del vil fortone seg temmelig likt for dem alle tre.

Tredelingen er tydeligst for det overordnede personell ved anstaltene, da de i regelen vil ha en akademisk utdannelse. La oss eksempelvis se på hvordan norske anstalter idag er utstyret med de forskjellige grupper av overordnet personell, og hvordan deres stilling er i behandlingen. For å ta medisineren først, så er ordningen med fengselsleger gammel og innarbeidet. Særlig overlege Scharffenbergs mangeårige virke ved Botsfengslet har bidradd til å grunnfeste psykiaterens posisjon i vårt fengselsvesen, også når det gjeller behandligen av presumptivt normale fanger. Han unders $\varnothing$ ker alle som settes inn, beholder kontakten med de fanger som trenger det, og deltar i alle fengselsrådets avgjørelser om samtlige. Der hvor det gjeller psykisk avvikende fanger, vil han i regelen være den som bestemmer. Fullt utbygget er denne ordning bare ved Botsfengslet, hvor der er en psykiatrisk overlege $\mathrm{i}$ heldagspost, og med et mindre fengselssykehus til sin rådighet for behandling av interkurrente sykdommer av somatisk eller psykisk art. Han har en psykiatrisk reservelege og en assistentlege foruten konsulenter i andre spesialiteter, men har altså ikke tilstrekkelig personale til å løse alle de behandlingsoppgaver som naturlig faller på ham. Psykopatanstalten på Ila har en liknende ordning, med en psykiatrisk overlege og reservelege, som har for liten hjelp til å makte alle behandlingsoppgaver. Den centrale tvangsarbeidsanstalt Opstad har en psykiater i full post, som dog ved siden av fører tilsyn med to mindre åndssvakeanstalter i samme distrikt, og som ikke har noen medisinsk assistanse. Ved de større kretsfengsler er gjerne fengselslegen psykiater, men bare i del-post. En liknende ordning er planlagt ved arbeidsskolen for unge lovovertredere på Berg, hvor der skal være en fast psykiatrisk konsulent. Vi har altså her grunnlaget for et effektivt system av behandlende leger i fengselsvesenet, men det trenger i h $\varnothing \mathrm{y}$ grad videre utbygning med flere faste stillinger, ikke minst for yngre folk. Derved vil man ikke bare kunne løse behandlingsoppgavene, men også sikre 
en bedre rekrutering, så der etterhvert vil oppstå en virkelig kriminalpsykiatrisk etat med terapeutiske hovedoppgaver. Idag er psykiaternes oppgaver i fangebehandlingen altfor meget innskrenket til å gjelle unders $\phi$ kelsen alene.

Den psykologiske sakkyndighet er bare rent sporadisk representert i norske fangeanstalter, og vi har ingen faste stillinger for dem. Det er her et utvilsomt behov. Alt nå har vi uteksaminerte psykologer som. er vel utdannet for visse unders $\varnothing$ kelsesmetoder som har betydning som ledd i behandlingen av kriminelle — og etterhvert vil de også få spe-sialutdannelse i visse typer av behandling. På de psykiatriske sykehus. hvor psykologer hittil er ansatt, har de vist seg à yde legene meget. verdifull assistanse. Etterhvert som sykehusene også får stillinger for underordnede psykologer, vil det bli utdannet folk som vil være vel skikket til å fylle stillinger i fengselsvesenet. Slike ,kliniske psyko-loger" vil være mere brukbare enn for eks. de psykologer som har sin. utdannelse og erfaring fortrinsvis i psykoteknikk og yrkesveiledning: - ikke minst når det gjeller behandlingsoppgaver.

Pedagoger har $i$ lang tid arbeidet $i$ våre fengsler, men mest som lærere, med den oppgave å meddele fangene kumnskaper. Dette er i og: for seg en nyttig oppgave, (og på mange vis en behandlingsoppgave) men utviklingen vil f $\varnothing \mathrm{re}$ med seg at de pedagoger som er knyttet til fengselsvesenet også kommer til å befatte seg mere direkte med behandlingen av fangene. „Pedagogisk behandling“ må selvsagt enhver som arbeider med kriminelle, drive. Men det finnes spesialoppgaver som den pedagogisk utdannede er særlig skikket til å løse.

Vi lrommer så til grupper av folk med høyere utdannelse som ikke uten videre passer inn $\mathrm{i}$ vårt tre-delte behandlings-skjema, de sosiologisk utdannede, eller m.a.o. de vel utdannede sosialarbeidere. Stillinger for såkaldte sosialsekretærer fins ved våre viktigste fengsler, og deres oppgave blir i første rekke kontakten mellem anstalten og utenverdenen. Sålenge interneringen varer, blir deres oppgave kanskje i f $\varnothing$ rste rekke av diagnostisk art, ved å legge materiale tilrette for en personunders $\varnothing$ kelse av fangen. Etter løslatelsen får de gjennem sitt follow-up arbeide også i høy grad behandlingsoppgaver.

Det teologiske element har fra gammelt av vært tillagt en viktig rolle ved våre fengsler, og hovedanstaltene har fremdeles hver sin prest $\mathbf{i}$ full stilling. Hans fremste oppgave blir å dekke fangenes religiøse behov, men det faller naturlig at han også kommer til å beskjeftige seg. med behandlingsoppgaver av pedagogisk eller psykologisk art - noe han også faktisk må gjøre for å fylle sin arbeidsdag. Man kan kanskje si at presten i behandlingssystemet vil kunne stå som representant for det etiske, personlige ansvar. Og hvis utviklingen skulle gå i rettning av å la behandling helt avløse straff, vil det være et behov for en hvis: særlige oppgave det er å ta vare på det menneskelige og rettslige gode. som et slikt ansvar betyr - et gode som nok kan komme til å bli truet hvis behandlingssystemet ikke innføres med skjønnsomhet. 
De juridisk utdannede har hittil vært de ledende i fengselsvesenet, og anstaltenes administrative sjefer har oftest vært jurister. Når det gjeller psykologisk eller pedagogisk behandling, kan det neppe hevdes at den juridiske utdannelse $\mathrm{i}$ og for seg gir noen fagkunnskap - hvis den ikke suppleres med studier i kriminologi langt utover eksamenspensum. Men det samme er jo tilfelle med legens stilling $\mathrm{i}$ den medisinske behandling: uten spesialutdannelse i psykiatri er han til liten nytte. Det er beklagelig at tilgangen til stillinger i fengselsvesenet fra juristenes leir er dårlig i Norge for tiden. Derfor skal man være oppmerksom på at det kan være betenkelig å gjøre juristenes arbeidsområde i våre fangeanstalter trangere enn det nå er — ved at man lar lege, psykolog og sosiolog skyve dem ut fra behandlingsoppgavene. Juristen ville dermed vesentlig få rent administrative oppgaver, og da kunde man like godt gå til å ansette en forretningskyndig mann som administrerende direktør.

Det vil nok i første rekke bli de overordnede som får ansvaret for behandlingen på en anstalt. Men det må ikke glemmes at hele atmosfæren på anstalten n $\varnothing$ dvendigvis vil bli et ledd $\mathrm{i}$ behandlingen, og denne atmosfæren preges i første rekke av de underordnede funksjonærer. Det er dem fangen er i direkte kontakt med det meste av tiden. De funksjonærer som har sin tidligere erfaring fra typiske straffeanstalter eller fra politiarbeide, vil lett få vanskeligheter hvis de skal gå over til en anstalt med utpreget behandlingssystem, fordi de er for festnet $i$ holdninger som henger sammen med straffen. Dette er viktig, fordi det idag er en praktisk nødvendighet at personalet på en behandlingsanstalt innen fengselsvesenet vesentlig rekruteres fra tidligere fengselsbetjenter og politifolk. De har betydelige fordeler ved sin erfaring i sikkerhetstjeneste og $\mathrm{i}$ omgang med fanger, men skal de fylle $\sin$. plass $i$ et behandlings-regime, trenger de spesialutdannelse for dette. Med årene vil nok behandlingsholdningen under enhver omstendighet arbeide seg inn hos de fleste av dem, men en slik omstilling kan gå hurtigere ved passende undervisningstiltak.

Folk med sykepleieutdannelse er det få av i norsk fengselsvesen, bortsett fra Fengselssykehuset. Selv på psykopatanstalten på Ila er det bare 5 diakoner ialt. Tilgangen er såvidt liten selv til de vanlige sykehus, at vi ikke på mange år kan vente noen større tilgang til fengslene, hvor hverken lønnen eller arbeidsforholdene byr på særlige fordeler. Dette er beklagelig, fordi fengselsvesenet utvilsomt har bruk for folk med den utdannelse, den praktiske erfaring og fremfor alt den innstilling som sykepleiere har, hvis behandlingslinjen skal kunne følges. Det kunne være tale om å opprette en spesialskole for personell til behandlingsanstalter for kriminelle psykopater o. l. men iallfall i Norge er behovet ikke stort nok for en selvstendig skole. Bedre vil det derfor være å trekke fangebehandling inn som et spesialfag på den skole som er planlagt for sinnssykehusenes pleiepersonell. Dermed får de naturlig tilknyttning til en etat som ved sin størrelse og sine tradisjoner 
kan sikre dem en god skole med førsteklasses lærerkrefter og en virkelig praktisk - klinisk undervisning ved siden av teorien.

I denne forbindelse meller seg spørsmål om kvinnelig personale på anstalter for mannlige kriminelle - ikke bare fordi tilgangen av kvinner til pleie-yrket er større, men særlig fordi kvinner ville være et nytt og verdifullt element $i$ et behandlingsregime. På alkoholistanstalter har det vist seg, både i Norge og i andre land, at et kvinnelig element betyr en stor vinning for anstaltens atmosfære. Hvorfor skal vi da være redd for å prøve dem på fengselsvesenets anstalter, hvor sikkerheten er langt større, og disiplinen sikkerlig ikke vanskeligere enn når det gjeller alkoholister?

På en behandlingsanstalt er arbeidet en av de viktigste terapeutiske metoder - en av de få som på en gang er medisinsk, psykologisk og pedagogisk. På sinnssykehusene, som her har særlig lang erfaring, har det vist seg at man som arbeidsledere først og fremst må ha folk som har erfaring i sykepleie, fordi pointet mere er å vekke pasientenes arbeidslyst enn å utføre håndverîsmessig førsteklasses arbeide. På fangeanstalter har kravet til kvalitetsarbeide større betydning, men håndverkskyndighet må likevel aldri bli det som veier tyngst når en arbeidsleder skal ansettes. Etterhvert som fengselsvesenets anstalter går mere og mere over fra håndverk til teknikk og mekanikk med fabrikksmessig drift, vil problemet kunne løsses ved at der ansettes en teknisk utdannet verkmester som produksjonsleder, mens den daglige arbeidsledelse ligger hos vel utdannede fengselsfolk med behandlingsinnstilling.

Personalspørsmålet kan altså ikke løses bare ved at nye stillinger blir opprettet - noe som for $\phi$ vrig i seg selv er vanskelig nok å fá til idag. Hver enkelt funksjonær, overordnet eller underordnet, må ha en utdannelse som gir ham muligheter for nogenlunde lett å leve seg inn i behandlingstanken. Heldigvis er det ikke n $\varnothing$ dvendig å vente til vi får skoler som gir oss et slikt personale fullt ferdig. Meget kan gjøres ved systematisk opplæring $\mathrm{i}$ dagliglaget av det personale vi nå har. Det er unødvendig å gå i detalj om de metoder som da kan komme på tale: forelesninger, spesialkurser osv. Jeg vil bare som særlig viktig fremheve gruppe-arbeidet. Vi skal komme tilbake til den velkjente gruppe-terapi, som ser ut til å bli så viktig for all fangebehandling men det er kanskje ikke så vel kjent at gruppearbeide med fangene alltid må ledsages av et tilsvarende gruppearbeide med funksjonærene. I slike gruppetimer kan de som deltar få meget nyttig teoretisk lærdom, som vil sitte desto bedre fordi de får den i forbindelse med drøftingen av konkrete fanger som de kjenner. Likeså viktig er det at gruppen gir funksjonærene anledning til å komme frem med sine personlige vanskeligheter i relasjon til arbeidet. Men fremfor alt gir det dem forståelse av at gruppens idé ikke består $\mathrm{i}$ at fangene skal få komme frem med ,klager på personalet" — en forestilling som har lett for å sette seg fast når gruppeterapien innføres på en anstalt.

Et av hovedpunktene i denne diskusjon er hvem som skal få behäd- 
ling av alle de som gjør seg skyldig i straffbare handlinger. Hvis man vil arbeide med et meget vidt behandlingsbegrep, kan svaret bli at alle skal ha behandling og ingen skal ha straff - og dermed har vi et typisk eksempel på den regel i logikken at hvis et begrep gjøres altfor vidt, blir det tomt og verdiløst. Behandling i egentlig forstand krever en spesiell innsats av tid, personell og penger — ved mange behandlingsmetoder er denne innsats til og med meget betydelig. Derfor er det av praktiske grunner n $\phi$ dvendig å gå til en „rasjonering“, og fordele den beskjedne behandlingsinnsats vi foreløbig kan makte, på de som trenger det aller mest. Selv blandt de sjelelig syke og abnorme kriminelle er det mange som det ikke lønner seg å ofre annen behandling på enn den som ligger i selve behandlingsanstaltens regime - så blir det desto mere tid til de som virkelig kan ha nytte av mere inngående terapeutiske tiltak. Også hensynet til behandlingspersonalet gjør dette n $\varnothing$ dvendig. Særlig i en tid da behandlings-synet skal innarbeides, er det viktig at man ikke forstrekker seg på forgjeves fors $\phi \mathbf{k}$ med ganske håpløse tilfelle. Det kan bare føre til motløshet og pessimisme. Et slikt prinsipp vil føre til at selv på de mest typiske behandlingsanstalter vil det ikke bli ofret like meget tid på alle, og dette kan tenkes å f $\varnothing$ re til missn $\varnothing$ ye. Derfor må alle ha et minimum av behandling, derved at de iallfall lever i en terapeutisk atmosfære, og med full adgang til å snakke ut om sine personlige bekymringer hvis de $\varnothing$ nsker det. Helst bør også enhver av belegget være knyttet til en eller annen aktiv behandlingsgruppe. De som kan ha grunn til å føle seg litt fors $\varnothing \mathrm{mt}$, vil i regelen kunne skaffes kompensasjon ved flyttning til friere avdelinger av anstalten 0.1 .

De fleste psykisk abnorme kriminelle har et klart og ofte stort behandlingsbehov. Derfor vil anstalter som spesialiserer seg på slike, bli utpreget behandlingsanstalter. Noe mere tvilsomt stiller det seg for de presumptivt psykisk normale. Her vil den mere intensive individuelle behandling bli mere sjelden, selv om ethvert fengsel avgjort b $\phi \mathbf{r}$ gi en fange full adgang til slik terapeutisk kontakt hvis han føler behov for det. Gruppe-terapi vil etterhvert vise seg verdifull også for disse fanger, men ellers blir det mest tale om å gjøre fengselsregimet så behandlingspreget som det praktisk lar seg gjøre. Meget vesentlig er den behandling som ligger i ettervernet etter løslatelsen — og i tilsynet med slike som har fått betinget dom eller påtaleundlatelse - her står vi overfor situasjoner hvor en individuell behandling i egentligste forstand er påkrevet også overfor psykisk helt normale.

Målet for behandlingen er i første rekke å hindre tilbakefall til ny kriminalitet. Dette primære behandlingsmål tjener i første rekke den offentlige sikkerhet. At en person holder seg ustraffet, behøver nemlig ikke å bety at man også har hjulpet ham frem til en god personlig tilpassning til livets problemer.

Det mest ergjerrige mål er å forandre hele personlighetens struktur, fordi det er her vi ofte finner de viktigste årsaker til kriminaliteten. Teoretisk finnes det muligheter for en slik dyptgående forandring av 
den menneskelige personlighet. Psykoanalytikerne hevder at det kan oppnåes ved en årelang analytisk behandling, men en slik terapi er så dyr og så langvarig at den bare i undtakstilfelle kommer på tale overfor kriminelle. Likevel kan nettopp slike sjeldne tilfelle være så viktige at et fullt utbygget fengselsvesen bør ha muligheter også for slik behandling.

En mere rask og radikal metode er den operative. Ved såkallt leukotomi (overskjæring av visse fibrebaner i hjernens pannelapp) kommer det $\mathrm{i}$ regelen en omstemning av personligheten $\mathrm{i}$ rettning av nedsatt følelsesmessig spenning — særlig når det gjeller slike følelser som angst, bekymring, agressivitet og skyldf $\phi$ lelse. For kriminelle av den holdningsl $\varnothing$ se type vil en slik operativ behandling ikke passe, fordi den lett kan gjøre dem enda mere sorgl $\varnothing$ st egoistiske enn f $\varnothing \mathrm{r}$. I England har man faktisk $\mathrm{i}$ enkelte tilfelle gjort slike uheldige erfaringer. På den annen side fins det typer hvor kriminaliteten helt eller delvis kan føres tilbake til en uheldig oppladning med bittre, depressive og agressive følelser, som så med mellemrom eksploderer i asosiale handlinger. I slike tilfelle er det teoretisk sandsynlig at faren for gjentakelse kan reduseres ved en leukotomi, og erfaringen har i noen tilfelle kunnet bekrefte dette. Hvor store muligheter denne "psyko-kirurgi“ har i fremtiden, er det idag vanskelig å ha noen bestemt mening om.

En tredje behandlingsmetode som sikter på en forandring av personligheten (på et spesielt område) er kastrasjonen. Ved siden av hovedvirkningen på selve kjønnsdriften, kan man i visse tilfelle se en bivirkning i form av nedsatt agressivitet og emosjonell spenning. Om dette skal regnes for en fordel eller for en uheldig komplikasjon avhenger av det enkelte tilfelles egenart.

Ingen av disse spesialmetoder, som setter seg så ergjerrige mål, vil komme til å bli særlig hyppig anvendt overfor kriminelle. Oftest må man nøye seg med nærmere og mere beskjedne mål. Det kan for eks. bli tale om en modning av personligheten - noe som ofte er aktuelt, fordi så mange av de kriminelle er psykisk uutviklet (infantile). En slik modning kan finne sted uten noen særbehandling, simpelthen ved at alderen f $\varnothing$ rer den med seg. Dette er hovedgrunnen til den erfaring at ikke få kriminelle faller til ro når de kommer opp i 40 - 50 års alderen. Man har også lov til å tro at regimet i en vel ordnet anstalt fremmer en slik modning, og pedagogiske, psykologiske og medisinske behandlingsmetoder vil her kunne være til god hjelp — snarest da i form av en psykoterapi av typen "direction morale.“

I svært mange tilfelle må vi renonsere på en virkelig forandring av personen selv og hans tilpassning til verden i almindelighet, og nøye oss med å få ham til å avholde seg fra fortsatte kriminelle handlinger. I visse patologiske tilfelle vil da den underlige ting kunne henne at de tendenser som ikke lengere får utl $\phi p$ i form av kriminalitet, isteden slår ut som nervøse symptomer eller $\emptyset$ ket personlig tilpassningsvanskelighet. Ikke mindst er dette å vente der hvor vi venner fangen av 
med alkoholforbruk som løsning på livets problemer, uten egentlig å gi ham noen annen og bedre metode isteden.

I noen tilfelle blir oppgaven å behandle en kompliserende sinnslidelse, som kanskje er oppstått under fengselsopphold, eller som iallfall bare mere perifert henger sammen med kriminaliteten. En overflyttning til psykiatrisk sykehus vil (i Norge) støte på praktiske vanskeligheter og plassmangel. Desuten er det tvilsomt om det i prinsippet er noen heldig løsning. Under enhver omstendighet $b \phi r$ fengselsvesenet være utstyrt med en sykeavdeling for behandling av slike tilfelle. Målet blir å få fangen tilbake til det vanlige behandlingsregime utenfor sykeavdelingen. I enkelte tilfelle har neurosen spilt en rolle for den kriminelle utvikling, og da kan man ved å behandle den oppnå $\phi k e t$ sikkerhet mot kriminelt recidiv.

Av mulige behandlingsmetoder er leukotomien og psykoanalysen alt nevnt. En tredje spesialmetode er narko-analysen, som består i at man setter hjernens hemmende og kontrollerende instanser ut av funksjon med raskt virkende narkotika, og gjør bruk av denne tilstand til å få bedre kontakt med pasienten. Hensikten kan være diagnostisk - altså å få tak på opplysninger som pasienten normalt vil forholde oss. En slik bruk av narkoanalyse kan være berettiget også overfor kriminelle hvis man holder seg strengt for $\phi y e$ at det ikke må få noe preg av å „lokke tilståelser ut" av vedkommende. Derfor må full frivillighet være en selvf $\varnothing$ lge, og det stoff som kommer frem må aldri benyttes $i$ en rettssal, eller overhodet når det gjeller å bestemme fangens skjebne. I andre tilfelle brukes narkoanalysen som behandling - særlig ved de svære og akutte neuroser, som ikke helt sjelden opptrer i fengselsmiljø. Betenkeligheten er da fremfor alt at mange av de kriminelle på forhånd har svakhet for narkotika, og derfor kan like behandlingen litt for godt.

Konvulsivbehandling og komabehandling (de såkallte sjokk-behandlinger) har ubrukte muligheter overfor psykisk abnorme kriminelle, og da ikke bare når det gjeller behandlingen av interkurrente psykoser i interneringstiden. Erfaringen fra sinnssykehusene viser at ikke få psykopater får avlastning for oppladede depressive $f \phi$ lelser ved slik behandling, slik at de føler seg mere vel, og blir lettere å ha med å gjøre. Det måtte selvsagt alltid foregå på helt frivillig basis, og noen betenkelighet skulle da slike terapeutiske fors $\phi k$ ikke by på. På fengselssykehuset i Oslo har det faktisk vist seg at man kan oppnå visse resultater, iallfall når det gjeller sosialisering innen anstalten.

At legemlige sykdommer og skavanker skal behandles, er det full enighet om. Her skal bare pekes på den betydning dette kan ha for fangens selvaktelse, og ikke mindre for hans innstilling til anstalten og til myndighetene overhodet. Et gebiss eller en brokkoperasjon blir dermed ikke sjelden effektive midler når det gjelder å påvirke en fanges sinnstilstand og bedre hans sosiale tilpassningsevne.

Et viktig spesialproblem er behandling av kronisk alkoholisme, som jo ikke bare er en hyppig komplikasjon hos kriminelle, men ofte likefrem en av de viktigste årsaker til kriminaliteten. Det vil f $\varnothing$ re for vidt 
å rulle opp hele problemet om alkoholistbehandlingen, men det er viktig å være klar over at vi nettopp her og nu befinner oss i en brytningsperiode. Den klassiske metode med et års opphold i lukket kuranstalt, har aldri kunnet dokumentere særlig gode resultater, og har for en del vakt uvilje og motstand hos alkoholistene. Dette er bakgrunnen for den bevegelse som i de fleste land kalles „A. A.“ (anonyme alkoholikere), og hvis idé er at „dette skal vi klare selv“ ved å hjelpe hverandre og uten frihetsber $\emptyset$ velse. Der legges stor vekt på å få vekk alt preg av straff, fordi alkoholismen er en sykdom og intet annet, og derfor bare krever behandling. En viss underbetoning av personens eget ansvar, og en litt vel agressiv holdning overfor myndighetenes mer eller mindre vellykkete tiltak har delvis preget denne bevegelse - som jo i sitt vesen er en slags vekkelse, båret oppe av følelser mer enn av resonnement.

I den mere „offisielle“ alkoholistbehandling er to ting kommet opp som delvis kommer kravene fra A. A.-bevegelsen imøte. Jeg sikter dels til innføringen av kortere og mere individuelt varierte kurtider, og til de åpne kurhjem hvor pasienten under kurtiden kan skjøtte sitt arbeide ute i byen. Dels sikter jeg til antabus-behandlingen, som jo også i prinsippet skal foregå i full frihet, men som jeg her ikke kan komme nærmere inn på.

Den viktigste form for behandling blir imidlertid psykoterapien i alle dens mange former. Enkelte fellestrekk ved all psykoterapi er av særlig betydning når det gjeller kriminelle. Meget viktig er det å erkjenne at man ikke streber etter noen ensretting, men heller etter å nytte ut best mulig de personlige egenskaper hver enkelt fange nå engang har. Det gjeller å finne frem til de positive trekk som alltid vil finnes i hans bakgrumn av miljø og personlighet, og stille dem konstruktivt opp mot de negative slik at det kan nyttes ut $\mathbf{i}$ behandlingen.

Meget viktig er det videre at all psykoterapi forutsetter det vi kaller den terapeutiske situasjon. Det dreier seg her om en egenartet personlig kontakt mellem pasient og terapeut, som i vårt spesielle tilfelle kanskje først og fremst består $i$ at fangen oppfatter seg som en person som trenger behandling og som får hvad han trenger - ikke som en der mottar straff, fordi han fortjener det (eller kanskje skjønt han ikke fortjener det). Her står vi rimeligvis overfor det vesentligste skille mellem behandling og straff: at formen for personlig kontakt blir radikalt forskjellig.

Denne personlige kontakt kan være av pedagogisk eller psykologisk eller medisinsk (psykiatrisk) art, alt etter hvem som utø̋ver behandlingen. For å oppnå kontakten trengs det nok endel praktisk erfaring, og kanskje bør man også ha inn $\varnothing$ vet bestemte spesialmetoder. Men det som fremfor alt må til (foruten den rette personlige innstilling til oppgaven) er tid og atter tid. Der kreves såvidt megen tid at det tør være tvilsomt om en terapeut kan ha mer enn 40-50 gjennemsnittlige fanger under behandling på samme tid, og selv dette tall blir bare mulig ved relativt lang gjennemsnittlig interneringstid. Når det gjeller tera- 
peutens innstilling til sin oppgave, vil det ved vanlige neuroser være en hovedoppgave å frigjøre pasienten fra visse sosiale hemninger. Her kan forholdene ligge noe anderledes an i arbeidet med kriminelle, hvor det kan være mere n $\varnothing$ dvendig å dempe ned sjelelige stormer, og hvor frigjøring av agressive og seksuelle tendenser må skje under særlig god kontroll. Derfor vil visse psykoterapeutiske metoder være mindre egnet nettopp innen et fengselsvesen — jeg tenker for eks. på đen Reichske form for psykoanalyse, hvor det kan bli tale om å få pasienten til å ta sitt sosiale ansvar noe lettere enn før, for dermed å overvinne hemninger. Om denslags kan være fullt forsvarlig overfor neurotikere, t $\not r$ det være en risikabel metode overfor kriminelle psykopater.

Det er ellers et vesentlig punkt at enhver terapeut får finne frem til den metode som passer ham selv best. Psykoterapi er en sterkt personlig sak. Den som har vært heldig med sine resultater, har en naturlig trang til å danne skole, men lengere kan man heller ikke gå. Ingen har rett til å hevde at hans spesielle metode i prinsippet er bedre enn alle andre.

Gruppebehandling står i en særstilling blandt de psykoterapeutiske metoder - både fordi den kræver mindre innsats av tid per behandlet individ, og fordi den synes å være særlig vel skikket overfor kriminelle. Vi må rimeligvis være forberedt på at det vil bli noe vanskeligere å innf $\phi r e$ den i Norden enn i anglosaksiske land, fordi folkekarakteren (bortsett fra Danmark) er noe mere preget av reservasjon og innesluttethet.

I psykoterapien på sykehus blir det ofte gjort bruk av en trekantet behandlings-situasjon: Pasienten er på samme tid i kontakt med to personer. Den ene representerer det forstående, ettergivende „moderlige" om man vil, og denne blir da den egentlige terapeut. Det tredje ledd $\mathrm{i}$ triangelen representeres av den administrative overordnede, som sørger for orden og disiplin og griper inn med strenghet og restriksjoner når det trengs. Pasientene identifiserer lett disse to med foreldrene, som jo ikke sjelden har foretatt en liknende arbeidsfordeling seg imellem. På en anstalt for kriminelle har en slik trekant-situasjon særlig lett for å utvikle seg, og kan sikkert være både praktisk og effektiv. Den gjør det mulig å stille fangen overfor to forskjellige holdninger, som vanskelig kan forenes i samme person.

I gruppe-terapien finner vi det samme, og her er det for eks. viktig at gruppe-lederen aldri må være en overordnet.

Sןørsmålet om hvor langt man kan vente å komme ved å innføre slike behandlingsprinsipper i fangebehàndlingen, lar seg idag vanskelig besvare med sikkerhet. I psykiatrien har analoge metoder vært brukt i årtier, men tross energiske og systematiske fors $\varnothing \mathbf{k}$ vet vi fremdeles lite om hvor gode resultatene egentlig er. Dette gjeller til og med enkle og konkrete behandlingsmåter som sjokkbehandlingen — og da selvsagt $\mathrm{i}$ enda langt større utstrekkning alt som heter psykoterapi. Ikke noe er mere usikkert enn behandlingsstatistikker, og en usikker statistikk er mere til skade enn til gagn. Derfor er vi fremdeles i lang 
tid henvist til å velge våre behandlingsmetoder ettersom de virker plausible, bed $\varnothing \mathrm{mt}$ etter det vi vet om lovmessigheten i den menneskelige adferd. Så prøver man seg frem med disse plausible metoder, og er takknemlig for de enkelt-suksesser man på kort sikt kan oppnå. Blir resultatet i første omgang tilsynelatende oppmuntrende, går man videre på samme vis, inntil erfaringene hoper seg opp og vinner i beviskraft. Kontrollfors $\varnothing \mathrm{k}$ blir det sjelden adgang til å ta i bruk. Slik grov empiri står ikke for streng kritikk — men skulle vi kreve rent laboratoriemessig stringens, ville det $\mathrm{i}$ praksis bare f $\varnothing \mathrm{re}$ til nihilisme og passivitet. Derfor er slike krav da også ofte bare maskert reform-fiendtlighet. En ting er sikkert nok: All behandling som utfores samvittighetsfullt og med ærlig registrering av resultatene, gir iallfall erfaring, og representerer derfor det uundværlige forskningsarbeide som utviklingen må bygges opp på. Når det gjeller motsettningen behandling contra straff, kunne man jo også svare med motspфrgsmålet: Hvad vet vi om straffens resultater?

En sikker erfaring fra all psykiatrisk behandling er at man må komme til så tidlig som mulig om man vil oppnå resultater, og det samme gjeller også for behandlingen av kriminelle. På grunnlag av vår almindelige medisinske erfaring er det ikke rimelig å tro at kriminalitet som har vart i over 5 til 10 år er særlig tilgjengelig for behandling. Likeså sikkert er det imidlertid at man kan få overraskelser, og at man skal være varsom med å avskrive et menneske som „,upåvirkelig“. Her kommer vi da i uløselig motsettning til n $\varnothing$ dvendigheten av å innskrenke våre behandlingstiltak til det antall vi kan makte sålenge midlene er begrenset.

Kriminalpolitisk og administrativt ligger den beste $1 \varnothing$ sning idag ikke i slagordet "behandling istedenfor straff“, men snarere i en gradvis utjevning av motsettningen. En slik utjevning kan skje på flere fronter. På personalfronten må den skje ved at alt personell som får med kriminelle å gjøre, får en opplæring som gjør det mulig for dem å innta en balansert holdning til spørsmålet om straff og behandling. Dette er langt å foretrekke for en politikk som vil skaffe oss to stridende grupper av spesialister, som er "tilhengere“ av hvert sitt system, og som ser på hverandre med misstro. Av dette følger så en tilsvarende utjevning for anstaltenes vedkommende. Rene straffeanstalter b $\varnothing$ r ikke lengere forekomme - og forsåvidt heller ikke ensidige behandlingsanstalter. Dette utelukker ikke at en større anstalt har sitt spesialpersonale og sine spesialavdelinger for behandling, eventuelt for spesielle behandlingsmåter. Tvertimot vil en slik spesialisert service innen anstalten være et mektig middel i utjevningens tjeneste.

Videre må der skje en utjevning i de midler som brukes, slik at man arbeider seg vekk fra straffemåter som inneholder lite av behandlingsprinsippet (eller kanskje likefrem strider mot det) og heller konsentrerer seg om de metoder som i sitt vesen er terapeutiske. Også overfor den enkelte fange kan det være mere konstruktivt å fremheve utjevningen, enn ensidig å forklare ham at han er under behandling eller 
under straff. På den måte undgår man lettere å ber $\emptyset v e$ de lettere psykisk abnorme deres f $\varnothing$ lelse av ansvar og personlig egenverd mere enn strengt n $\varnothing$ dvendig. Det ville være en fare for den sunde utvikling om vi skulle drive inn i et terapiens opplyste enevelde, hvor den enkelte lovbryter er uten beskyttelse mot de behandlingstiltak som en velmenende samfundsmakt setter i sving overfor ham. Under slike forhold kan vi risikere at selv den mest rasjonelle og humane behandling virker trykkende. Vi må vokte oss vel for å få domstolene, hvor den enkelte borger $d \varnothing$ mmes av sine jevnlike, erstattet med en totalitær kriminologi hvor vitenskapelig velfundert den enn med tiden måtte bli.

Den taktiske fordel ved en utjevningslinje kommer særlig tydelig frem når vi tenker på alt det mentalhygieniske opplysningsarbeide som trenges omkring kriminalitetens problemer. Legger vi denne opplysningsvirksomhet ensidig an etter den linje at de som begår straffbare handlinger igrunnen er uansvarlige mennesker, viljel $\phi$ se ofre for sine egne sykelige tendenser og for samfundets brøst, vil det være vanskelig å undgå alvorlige konflikter med den almindelige rettsbevissthet — kanskje vil vi også oppnå a skape forvirring der hvor vi ville bringe klarhet. Noe annet er at utjevningen ikke kan være nфytral og rettningsløs, men må ha en tydelig tendens hen mot behandlingspolen. Det er en naturlig følge av at vi idag altfor ensidig bygger på straffen.

örnulv ödegård. 